\title{
Risk Map for a Selected Organization
}

\author{
Dorota Wojtyto, Joanna Michalik, \\ Sandra Kobuszewska \\ Czestochowa University of Technology, Poland
}



Date of submission to the Editor: 09/2019

Date of acceptance by the Editor: 11/2019

\section{INTRODUCTION}

Risk mapping and analysis of risk maps for a particular facility or complex of facilities (the enterprise and its environment, administrative units, etc.) is preceded by a risk management process (Bac M. 2010), First and foremost, proper identification of hazards that could compromise the safety of the examined facility is crucial. Hazards can be of both concentrated and spatial nature (this applies especially to dynamic hazards, with a tendency to spread and increase their impact). The next stage of the risk management process is risk analysis, i.e. determination of the probability of occurrence of a particular hazard and the consequences of the hazard. Risk value allows to estimate risk level (whether acceptable or not), which is the assessment stage (PN-ISO 31000:2018, Guadliness for Quantitative Risk Assessment 1999). At this stage, risk mapping, which constitute a visual presentation of a particular hazard, is considered to be useful (De Chano L.M.et al. 2001). Risk maps allow to identify high hazard zones within a particular area, and then to take relevant actions (Wojtyto 2016, Kaczmarek 2010, Manuel E. 2007).

The definition of a risk map implies that it is a map or description showing potential negative consequences of hazards on people, property, environment, and infrastructure, together with the probability of occurrence of the hazards (Hartono et.al 2019, Maud Boriea et. al). Whereas a hazard map is the geographical area covered by the extent of the hazard, taking into account various scenarios. Thus, the difference between a risk map and a hazard map is that the former includes, in addition to the probability of occurrence of a particular hazard, its consequences, and thus the estimated risk (Christou M.D.2000, Jokman S.N. 2003). The visualization can be made for partial risk, taking into account one hazard, as well as for total risk, covering all the hazards occurring within a particular area (Wróblewski 2015, Skomra 2015).

The recipients of hazard maps and risk maps can be various authorities responsible for safety management or private entities. The maps should be appropriate to the requirements of the said authorities, and therefore their 
content may vary. The maps form the basis for appropriate actions aimed at improving safety, e.g. preventive actions that will reduce the frequency of adverse events and lower the level of consequences (Maps of Territorial Risk Distribution, 2004, Wróblewski 2014).

Risk mapping is a process consisting of several stages. Figure 1 presents the general methodology of such mapping.

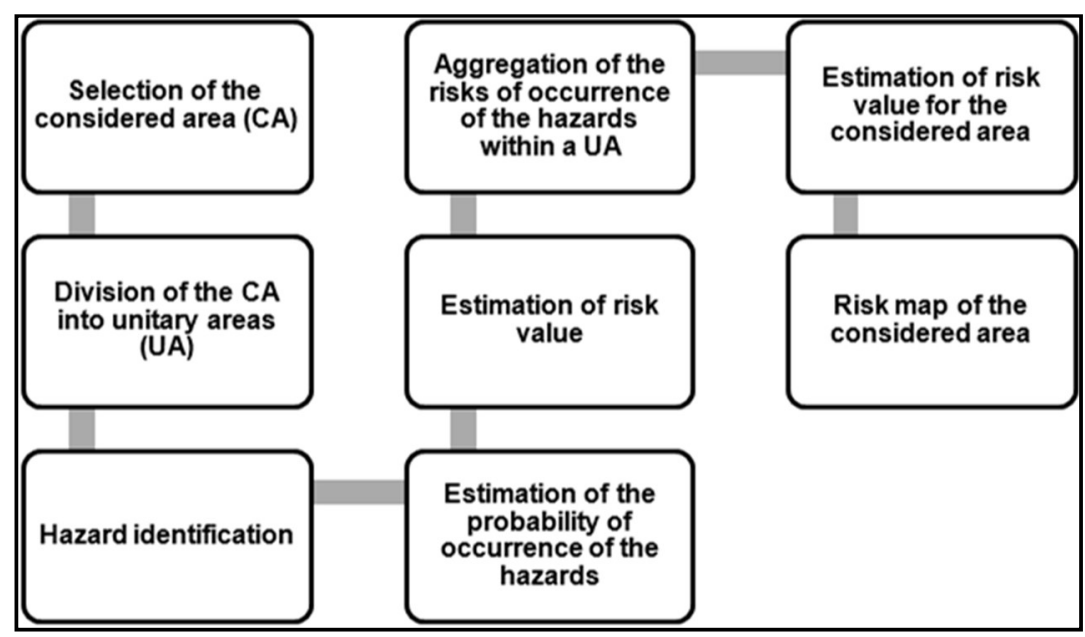

Source: (Skomra 2015)

Fig. 1 Stages of risk mapping

The first stage of risk mapping is selection of the analyzed area, the so-called Considered Area (CA). The examined area is selected on the basis of individual criteria of the future map user. The second stage is division of the analyzed CA into individual areas, the so-called Unitary Considered Area (CUA). The Considered Area is divided into smaller Considered Unitary Areas (Szopa et.al). This division is necessary due to a better understanding of the hazards and risk values occurring within the examined area (Skomra 2015). Unitary areas should be of the same surface area and construction. One of the best criteria to be applied while dividing the CA into CUAs is risk uniformity. Uniform risk can be defined as risk that fulfils the following conditions: risk on each part of the divided area is the same or there is a minor difference. The best method to portray CUAs is by means of rectangles or squares. Their size can be different, but it is important that risk presented on each of the CUAs is uniform. In order for the division of the CA into unitary areas to be accurate, it is necessary to determine the geographical coordinates of the selected area, i.e. longitude LON and latitude LAT. The coordinates are used to determine the beginnings and ends of the unitary areas, so that in the subsequent part of risk mapping, it is possible to determine the distribution of risk level within a particular unitary area. The third stage is to overlap the risk with a Considered Unitary Area. The colors put on the map indicate the level of risk, e.g. green indicates acceptable risk, while red indicates very high risk and yellow indicates medium risk. Therefore, risk map analysis allows to establish preventive actions (control mechanisms), what occurs later in the risk management process, at the risk response stage (Skomra 2015). 


\section{RESEARCH METHODOLOGY}

The primary purpose of this paper was to create a risk map for the selected organization. A risk map takes into account external risks, identified in the risk management process, to which enterprises are exposed in the course of their business operations and within the administrative area in which the enterprises operate (Cox L.A. 2008). The risk analysis and assessment were carried out by means of a standard risk matrix. The subject of the research is an organization engaged in the production of railway vehicles. The organization is composed of 22 production halls and one office building. The considered area was the premises of the organization and the surrounding and adjacent areas with potential impact on the activity of the examined facility (Hubbard D. 2009). For risk mapping, analyses of documents provided by the organization and interviews with employees as well as visual tools were used in the paper (Kobuszewska 2017).

\section{RESULTS}

The first stage of the risk management process, which is the basis for risk mapping of the examined facility, was the identification of external hazards, i.e. those which are not caused by the activity of the organization, but derive from external factors (natural hazards, hazards resulting from the activity of neigh boring entities, external technical hazards).

Table 1 Identification of external hazards for the examined organization

\begin{tabular}{|c|c|c|c|c|}
\hline No. & Hazard type & $\begin{array}{c}\text { Causes } \\
\text { of occurrence }\end{array}$ & Consequences & Probability \\
\hline $\mathrm{Z}_{\mathrm{z} 1}$ & $\begin{array}{l}\text { Fire of the } \\
\text { service station } \\
\text { located } 250 \mathrm{~m} \\
\text { from the } \\
\text { examined facility }\end{array}$ & $\begin{array}{l}\text { Leakage of fuels, } \\
\text { flammable materials, } \\
\text { and formation of } \\
\text { spark which ignites } \\
\text { these materials }\end{array}$ & $\begin{array}{l}\text { Possibility of one of the buildings } \\
\text { of the examined } X \text { facility going } \\
\text { on fire, extensive damage, } \\
\text { probability of a large number } \\
\text { of personal injuries }\end{array}$ & $\begin{array}{l}\text { The event } \\
\text { has not } \\
\text { occurred } \\
\text { in the past }\end{array}$ \\
\hline$Z_{z 2}$ & $\begin{array}{l}\text { Fire of the } \\
\text { ironworks } \\
\text { located } 450 \mathrm{~m} \\
\text { from the } \\
\text { examined facility }\end{array}$ & $\begin{array}{l}\text { Self-ignition } \\
\text { of flammable } \\
\text { substances used } \\
\text { in the technological } \\
\text { process }\end{array}$ & $\begin{array}{l}\text { Possibility of one of the buildings } \\
\text { of the examined XYZ facility going } \\
\text { on fire, probability of personal } \\
\text { injuries, substantial financial } \\
\text { losses }\end{array}$ & $\begin{array}{l}\text { The event } \\
\text { has not } \\
\text { occurred } \\
\text { in the past }\end{array}$ \\
\hline $\mathrm{Z}_{\mathrm{z} 3}$ & Bumping & $\begin{array}{l}\text { Natural hazard } \\
\text { caused by seismic } \\
\text { movements }\end{array}$ & $\begin{array}{l}\text { Damage to the structure } \\
\text { of one of the facilities of the } X Y Z \\
\text { organization, disruption of the flow } \\
\text { of the manufacturing process, } \\
\text { no personal injuries, low financial } \\
\text { losses }\end{array}$ & $\begin{array}{l}\text { Four times } \\
\text { over five } \\
\text { years }\end{array}$ \\
\hline$Z_{z 4}$ & $\begin{array}{l}\text { Gas explosion } \\
\text { in the nearby } \\
\text { residential } \\
\text { buildings located } \\
150 \mathrm{~m} \text { from the } \\
\text { examined facility }\end{array}$ & $\begin{array}{l}\text { Damage to the gas } \\
\text { system or deliberate/ } \\
\text { non-deliberate } \\
\text { actions of the } \\
\text { residents }\end{array}$ & $\begin{array}{l}\text { Strong explosion may damage } \\
\text { the structure of one of the facilities } \\
\text { of the examined } X Y Z \\
\text { organization, there is probability } \\
\text { of a large number of personal } \\
\text { injuries, including fatalities, large } \\
\text { financial losses, and massive } \\
\text { destructions }\end{array}$ & $\begin{array}{l}\text { The event } \\
\text { has not } \\
\text { occurred } \\
\text { in the past }\end{array}$ \\
\hline
\end{tabular}

Source: own work based on materials provided by the organization

As shown in Table 1, four major external risks were identified for the examined organization, such as fire of the service station and the ironworks neigh boring with the examined facility, bumping, and gas explosion in the nearby residential 
buildings. On this basis, a risk analysis was carried out by means of the risk matrix, according to the adopted criteria. For each hazard, the value of the probability of occurrence of the hazard and the value of potential consequences were determined using the formula: $R=P \cdot C$,

where:

$\mathrm{R}$ - means the risk value,

$\mathrm{C}$ - means the consequences value,

$\mathrm{P}$ - the probability value.

The calculations of the risk values for the identified hazards are presented in Table 4, while the criteria for risk analysis and assessment for probability and consequences are presented in Tables 2 and 3.

Table 2 Criteria of risk analysis and assessment - the probability value

\begin{tabular}{|c|c|c|}
\hline $\begin{array}{c}\text { Hazard } \\
\text { category }\end{array}$ & Characteristics & Description \\
\hline 1. & $\begin{array}{l}\text { Almost certain } \\
\text { event (more } \\
\text { frequent than once } \\
\text { per year) }\end{array}$ & $\begin{array}{l}32 \text { - These events occur in larger circumstances and/or are well } \\
\text { documented and/or exist among the residents/users and are } \\
\text { communicated orally. Probability of occurrence once per year } \\
\text { or more frequently. }\end{array}$ \\
\hline 2. & $\begin{array}{l}\text { Highly probable } \\
\text { event (from } 1 \text { to } 5 \\
\text { years) }\end{array}$ & $\begin{array}{l}16-\text { The events are expected to occur systematically and/or in } \\
\text { known circumstances, are well documented, communicated orally } \\
\text { and/or there is high probability of occurrence due to a known } \\
\text { process, device, or cause. Probability of occurrence over five } \\
\text { years. }\end{array}$ \\
\hline 3. & $\begin{array}{l}\text { Probable (from } 5 \\
\text { years to } 10 \text { years) }\end{array}$ & $\begin{array}{l}8 \text { - The events may occur in certain known or unknown } \\
\text { circumstances. Not properly documented, communicated orally. } \\
\text { Their occurrence is related to failure of equipment and/or } \\
\text { processes. Probability of occurrence over ten years. }\end{array}$ \\
\hline 4. & $\begin{array}{l}\text { Unlikely event (from } \\
10 \text { years to } 100 \\
\text { years) }\end{array}$ & $\begin{array}{l}4-\text { The events may occur at random, are documented and/or } \\
\text { function in social memory, and are communicated orally in } \\
\text { incomplete form. There are known devices, processes, or causes } \\
\text { which give rise to the likelihood of their occurrence. Probability } \\
\text { of occurrence over one hundred years. }\end{array}$ \\
\hline 5. & $\begin{array}{l}\text { Very rare event } \\
\text { (from } 100 \text { years } \\
\text { to } 500 \text { years) }\end{array}$ & $\begin{array}{l}2-\text { There is no documentation confirming the occurrence } \\
\text { of the events, the events are not present in oral transmissions, } \\
\text { the events have not occurred in similar organizations, equipment, } \\
\text { or processes. There is small likelihood of occurrence of the event. } \\
\text { Probability of occurrence over } 500 \text { years. }\end{array}$ \\
\hline 6. & $\begin{array}{l}\text { Impossible event } \\
\text { (more than } 500 \\
\text { years) }\end{array}$ & $\begin{array}{l}1-\text { Occurrence of the events is likely only in exceptional } \\
\text { circumstances. Probability of occurrence over more than } 500 \\
\text { years. }\end{array}$ \\
\hline
\end{tabular}

Source: (Skomra 2015)

Table 3 Criteria of risk analysis and assessment - the consequences value

\begin{tabular}{|c|l|}
\hline Characteristics & \multicolumn{1}{c|}{ Description } \\
\hline $\begin{array}{c}\text { A } \\
\text { negligible }\end{array}$ & $\begin{array}{l}\text { 1- Uninterrupted functioning of people or interruption only to a small extent. } \\
\text { Undisturbed processes. No environmental impacts. No human displacement } \\
\text { or damage. Discomfort. }\end{array}$ \\
\hline $\begin{array}{c}\text { B } \\
\text { small }\end{array}$ & $\begin{array}{l}\text { 2- No fatalities or personal injuries. No or little impact on the functioning } \\
\text { of the local community. Minor damage, unmeasurable environmental impact, } \\
\text { small financial losses. A small scale of human displacement, no one or a small } \\
\text { number of people require hospitalization. }\end{array}$ \\
\hline $\begin{array}{c}\text { C } \\
\text { medium }\end{array}$ & $\begin{array}{l}\text { 4- Damage to a certain extent has occurred. A small number of personal injuries, } \\
\text { some of the injured need help, first aid is required. No fatalities. Low } \\
\text { environmental impact. Small financial losses. Difficulties in the functioning } \\
\text { processes. }\end{array}$ \\
\hline $\begin{array}{c}\text { D } \\
\text { high }\end{array}$ & $\begin{array}{l}\text { 8- No fatalities, some of the injured need to be hospitalized. Evacuation } \\
\text { of people to properly designated areas. Identification of damage that needs } \\
\text { to be repaired. Large short-term environmental impacts or small long-term } \\
\text { impacts. Perceptible financial losses. Interruption in the functioning } \\
\text { of the population for more than 24 hours. }\end{array}$ \\
\hline
\end{tabular}




\begin{tabular}{|c|l|}
\hline $\begin{array}{c}\mathrm{E} \\
\text { very high }\end{array}$ & $\begin{array}{l}16-\text { Fatalities and/or a high number of serious personal injuries. A high number } \\
\text { of people requiring hospitalization. Some services are unavailable, a part } \\
\text { of the population is not functioning. Large financial losses and long-term } \\
\text { environmental impacts. Large scale of human displacement. }\end{array}$ \\
\hline $\begin{array}{c}\text { F } \\
\text { extreme }\end{array}$ & $\begin{array}{l}32-\text { A high number of fatalities and personal injuries. A large number } \\
\text { of hospitalized people. Very extensive damage. External financial assistance } \\
\text { needed, long-term environmental impacts. }\end{array}$ \\
\hline
\end{tabular}

Source: (Skomra 2015, Wróblewski 2014)

Table 4 Risk analysis of external hazards for the examined organization

Source: own work

\begin{tabular}{|c|c|c|c|}
\hline Hazard & Consequence value & Probability value & Risk value \\
\hline$Z_{z 1}(4, C)$ & 4 & 4 & 16 \\
\hline$Z_{z 2}(4, D)$ & 8 & 4 & 32 \\
\hline$Z_{z 3}(2, B)$ & 2 & 16 & 32 \\
\hline$Z_{z 4}(4, E)$ & 16 & 4 & 64 \\
\hline
\end{tabular}

Each of the identified hazards was put on the risk matrix, which is shown in Figure 2.

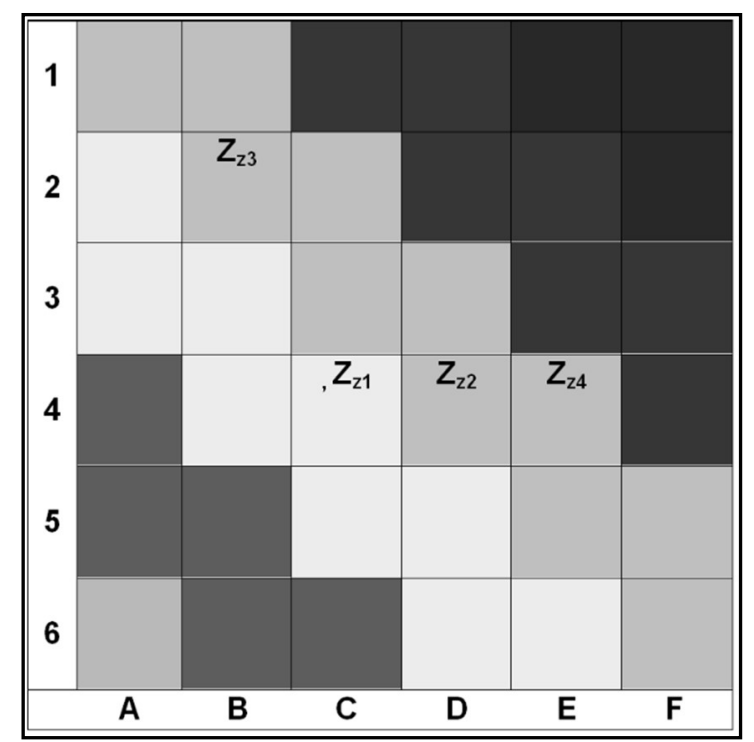

Fig. 2 Risk matrix of the external and internal hazards for the examined facility Source: own work based on: (Berg, 2014; Skomra 2015)

Table 5 presents the risk values and the corresponding risk levels for the identified external hazards.

Table 5 Risk level according to the standard risk matrix for the external hazards

\begin{tabular}{|c|c|c|}
\hline Risk value & Risk level (color) & Identified hazards \\
\hline 1 & negligible risk (green) & \\
\hline $2-6$ & small risk (blue) & $\mathrm{Z}_{\mathrm{z} 1}$ \\
\hline $8-16$ & medium risk (yellow) & $\mathrm{Z}_{\mathrm{z} 2}, \mathrm{Z}_{\mathrm{z} 3}, \mathrm{Z}_{\mathrm{z} 4}$ \\
\hline $32-64$ & high risk (orange) & \\
\hline $128-256$ & very high risk (red) & \\
\hline $512-1024$ & extreme risk (brown) & \\
\hline
\end{tabular}

Source: own work

As shown on the risk matrix presented in Figure 2, the highest risk level is associated with gas explosion in the nearby residential buildings located $150 \mathrm{~m}$ from the examined facility. The hazard of bumping has the highest probability of 
occurrence, and gas explosion in the nearby residential buildings leads to the most severe consequences.

Taking into account the above analysis performed by the visualization of the risk within the area of the examined organization. For this purpose, the considered area CA was selected, which includes the premises of the organization and the surrounding areas (within the radius of about one kilometer), which are the sources of the external hazards. Then, the considered area was divided into unitary areas UA in the form of squares of the same size. They were numbered 1-12. The division of the CA into CUAs is presented in Figure 3.

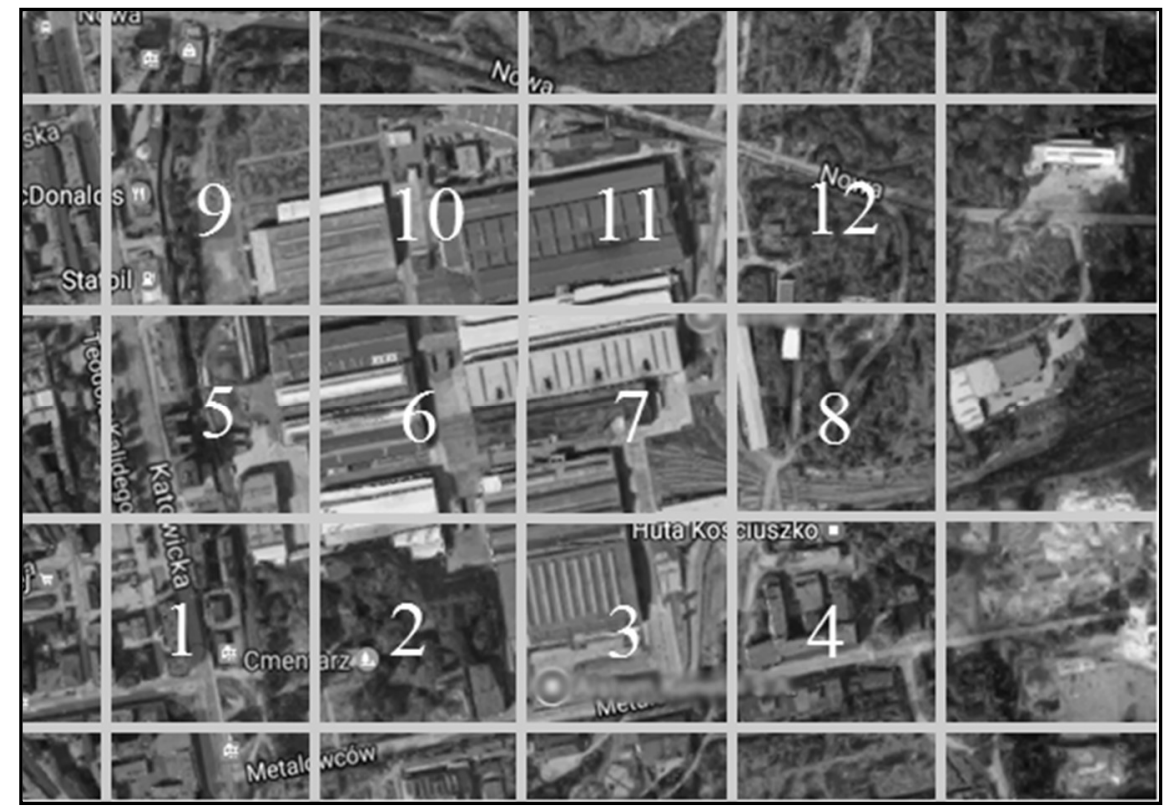

Fig. 3 Division of the considered area into considered unitary areas Source: own work based on www.mapy.google.pl [date of access: 14 January 2017]

As shown in Figure 3, the beginning and end of each of the CUAs marks the latitude and longitude. The starting and ending widths are the latitudes at which a unitary considered area begins or ends. The same is true of the starting and ending length, which marks the appropriate longitude. The squares in the figure portray the considered unitary areas (CUA) with the same surface area. The analyzed hazards are located in the CUAs no. 1, 2, 4, 5, 6, and 9.

On the basis of hazard identification as well as risk assessment and analysis, a risk map can be created for the external hazards for the $X$ organization. The identified hazards are located in the considered unitary areas 1, 4, 5, and 9. Risk analysis and assessment for the CUAs 1, 4, and 5 revealed that the level of risk is high, and for the CUA 9, it is medium. The distribution of risk on the map is shown in Figure 4.

The analyzed hazards reflected on the risk map of the examined facility require that actions aimed at reducing the risk level need to be taken. Risk management is as follows: negligible risk can be acceptable, low risk is also acceptable, but requires control. Medium risk requires a mock drill of actions. In the case of high risk, measures should be taken to reduce the risk and they need to be 
coordinated on an ongoing basis. In the case of large and extreme risk, there must be total risk reduction (Table 5).

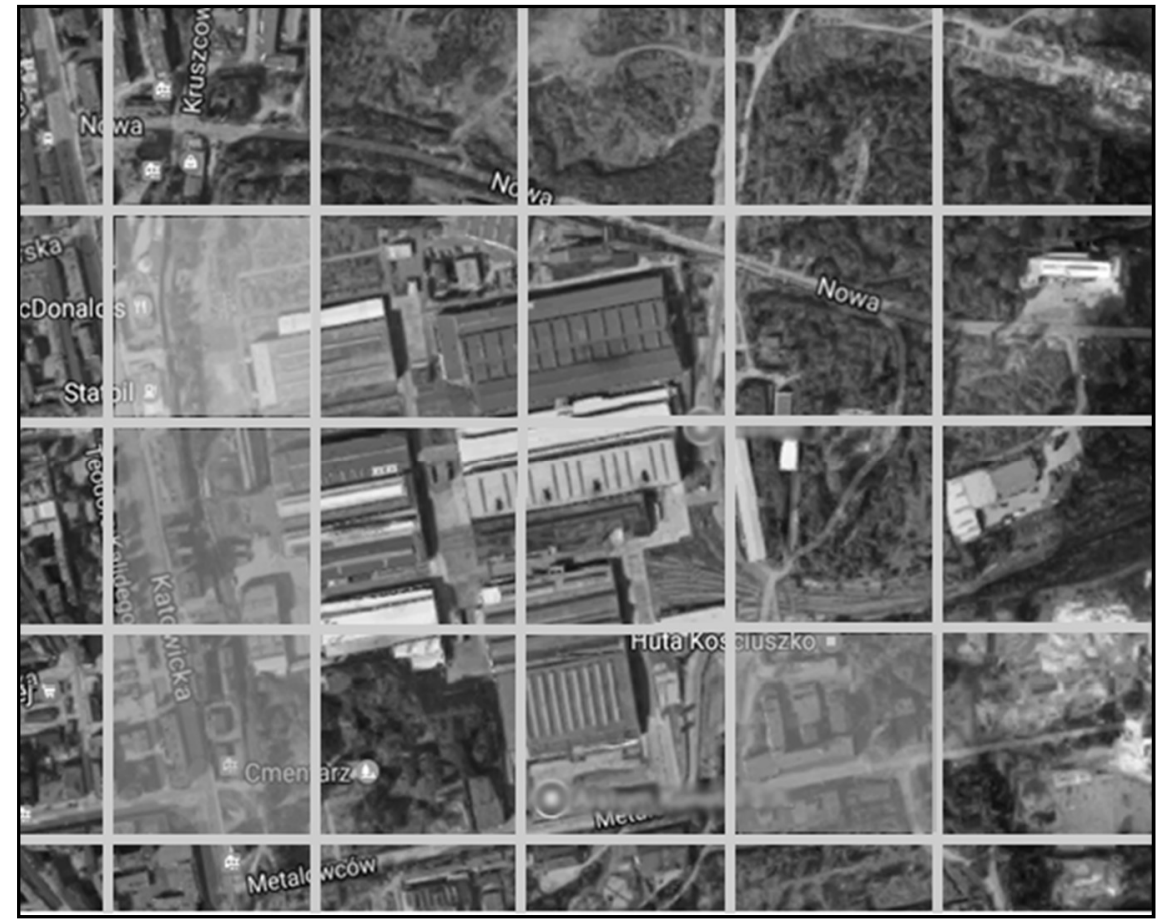

Fig. 4 Risk map of external hazards for the $X$ organization

Source: own work based on www.mapy.google.pl [date of access: 14 January 2017]

Table 5 Risks management concerning the six risk levels

\begin{tabular}{|c|c|c|}
\hline Risk value & Risk level & Risk management \\
\hline 1 & negligible & acceptance \\
\hline $2-6$ & low risk & acceptance, risk control \\
\hline $8-16$ & medium risk & mock drill of actions \\
\hline $32-64$ & high risk & actions to reduce the risk level and their coordination \\
\hline $128-256$ & very high risk & risk reduction \\
\hline $512-1024$ & extreme risk & risk reduction \\
\hline
\end{tabular}

Source: own work

Table 6 presents control mechanisms for the external risk values of the hazards for the examined organization (risk response).

Table 6. Risk response to the external hazards for the examined organization

\begin{tabular}{|c|c|l|}
\hline Hazard & Risk value & \multicolumn{1}{c|}{ Control mechanism } \\
\hline$Z_{z 1}$ & 16 & $\begin{array}{l}\text { Training of employees to react quickly in the event of a hazard. } \\
\text { Establishment of a rapid alert system and monitoring of its condition. }\end{array}$ \\
\hline$Z_{z 2}$ & 32 & $\begin{array}{l}\text { Reinforcement of the existing structures so that they do not cause damage } \\
\text { in the event of a hazard. Taking this hazard into account during construction } \\
\text { of new production lines. }\end{array}$ \\
\hline$Z_{z 3}$ & 32 & $\begin{array}{l}\text { Training of employees to react quickly in the event of a hazard. } \\
\text { Establishment of a rapid alert system and monitoring of its condition. }\end{array}$ \\
\hline$Z_{z 4}$ & 64 & $\begin{array}{l}\text { Training of employees to react quickly in the event of a hazard. } \\
\text { Establishment of a rapid alert system and monitoring of its condition. }\end{array}$ \\
\hline
\end{tabular}

Source: own work based on materials provided by the organization

The level of risk to the examined organization requires that specific actions be taken, aiming at risk reduction at least to the small level of risk, where the risk is acceptable and needs to be controlled. The consequences of ignoring the risk 
can be, among others, large financial losses, disruption of the flow of the processes of

the organization, and damage to the health of the employees. The organization is located in the vicinity of other production sites, what increases the risk level. An optimal solution to this situation could be cooperation with the neigh boring entities in risk management, consisting in establishment of a common risk prevention system. An important element in the reduction of the consequences of potential hazards is quick response, therefore it is noteworthy to consider creation of a rapid information exchange system, not only within the organization, but also extending it to

the neigh boring entities. Thanks to such a system, if a hazard occurs in the examined organization, the nearby plants, e.g. the ironworks, will be able to quickly respond to this hazard, and thus reduce losses.

\section{CONCLUSION}

Summarizing the considerations made in this paper, it can be concluded that risk mapping is a multi-stage process that is directly related to the risk management process. It requires correct identification of already existing hazards or such that will occur later, and then risk analysis and assessment of the hazards. With properly identified hazards, performance of risk analysis and assessment, and risk response,

a risk map in graphic form that presents accurate risk distribution and allows to take relevant actions to reduce the risk to an acceptable level can be designed. This makes it possible to locate a particular hazard and determine the possibility of its elimination or minimization. This tool is also useful to other entities interested in

the activity of an examined organization, including the area administrator, the administrative unit [commune, district or even region], neigh boring business entities and residential buildings, etc. A risk map is also useful to identify hazard zones within the local government unit, and to take appropriate crisis management measures.

In the examined facility, in addition to the external hazards, internal hazards can also be identified, such as: possibility of fire of hall 22, uncontrolled release of SOCOPAC 50s and Tectyl 506 chemical substances, chemical poisoning, chemical burn, probability of explosion or electric shock, and many others, which can also be put onto the risk map. Then, it is possible to overlay two maps for more precise determination of a potential risk zone and identification of hazard zones.

The research indicated the level of risk in the examined facility, thanks to which the knowledge of the hazards occurring within the area of the organization was improved both among the employees and the persons responsible for risk management in the organization. Knowing the level of risk is the first step to improving current safety. 


\section{REFERENCES}

Bac M. (2010), Models of risk management in organisations, The Małopolska School of Economics in Tarnów Research Papers Collection, iss. 2 (16) Tarnów

Berg H.P.(2014): Risk management: procedures, methods and experiences.

Christou M.D., Mattarelli M. (2000), Land- Use planning the vicinity of chemical sites: Risk informed decision making at local community level, Journal of Hazardous Materials 78, s. 191-222.

Cox L.A. (2008), What's Wrong wit Risk Matrices?, Risk Analysist, t. 28, nr 2.

Hartono, Budi; Wijaya, Deo F.; Arini, Hilya M. (2019) The impact of project risk management maturity on performance: Complexity as a moderating variable, International Journal of Engineering Business Management Volume: 11 Article Number: 1847979019855504 Reliability: Theory \& Applications, No. 1/2/17.

De Chano L.M., Butler D.R. (2001), Analysis of public perception of debris flow hazard, "Disaster Prevention and Management", Vol. $10 \mathrm{~N} 4$.

Guadliness for Quantitative Risk Assessment (1999), Purple Book CPR 18E

Hubbard D. (2009), The Failure of Risk Managemnt. Chp 7. Woirse than Useless The most popular risk assessment method and Why is dosesn't work, Wiley\&Sons

Jokman S.N. (2003), An overview of quantitative risk measures for loss of live and economic damage, Journal of Hazardous Materials A 99 (1-30).

Kaczmarek T. (2010), Zarządzanie ryzykiem [Risk Management], published by WNT, Warsaw.

Kobuszewska S. (2017), Projekt mapy ryzyka wybranego obiektu [Risk Map Project of a Selected Facility], thesis under the supervision of Dorota Wojtyto, PhD, Częstochowa, unpublished material.

Manuel E. (2007), Innovation and rsk mangement, MPRA Paper No. 2277, Posted 16 March

Mapy terytorialnego rozkładu ryzyka (2004) [Maps of Territorial Risk Distribution], Warsaw University of Technology, Faculty of Power and Aeronautical Engineering, the Main School of Fire Service, Centre for Education in Public Safety, Warsaw, pp. 31-37.

Maud Boriea, Gina Ziervogelb, Faith E. Taylorc, James D.A. Millingtona, Rike Sitasd, Mark Pelling (2019) Mapping (for) resilience across city scales: An opportunity to open-upconversations for more inclusive resilience policy? Environmental Science and Policy 99,pages 1-9

PN-ISO 31000:2018 - English version, PKN, Warsaw.

Skomra W.(2015) Metodyka oceny ryzyka na potrzeby systemu zarządzania kryzysowego RP [Risk Assessment Methodology for the Crisis Management System of the Republic of Poland], Warsaw.

Szopa T., Dietrich M. (2014), Zasady modelowania i szacowania ryzyka na określonym terenie. Mapy terytorialne i rozkład ryzyka [Rules of Risk Modeling and Assessment within a Selected Area. Territorial Maps and Risk Distribution], Warsaw.

Wojtyto D., (2016) Zarządzanie ryzykiem jako element zapewnienia bezpieczeństwa przedsiębiorstwa [Risk Management as an Element of an Organization's Safety Assurance], Chapter in the joint Monograph edited by Staniewska E., Mitkow Sz., Wybrane aspekty bezpieczeństwa w łańcuchach dostaw [Selected Aspects of Safety in Supply Chains], published by WIPiTM.

Wróblewski D. (2015): Zarządzanie ryzykiem - przegląd wybranych metodyk. CNBOPPIB Józefów.

Wróblewski D., Połeć B.: (2014) Teoria i praktyka zarządzania ryzykiem - normy a regulacje w prawie miejscowym, [w:] Majchrzak D. (red.): Zarządzanie kryzysowe w wymiarze lokalnym. Organizacja, procedury, organy i instytucje, AON, Warszawa. 
Abstract.

The publication presents a risk map for a selected organization concerning external hazards, i.e. those whose source is not derived from the internal conditions of the functioning of the organization. To this end, a risk management process was carried out, consisting in the identification of hazards, their analysis, risk assessment, and risk response. The risk map shows a visual presentation of these hazards together with the defined risk level. This map is used to identify hazard zones within the examined organization, serving as a database also for all entities interested in the business activity of the organization, the entities neighboring the facility, or private persons. Furthermore, this tool is particularly useful for local government administration units for the purpose of proper crisis management within the administered area. The risk map is also used to identify internal risk areas in the organization.

Keywords: risk map, hazard map, risk management 